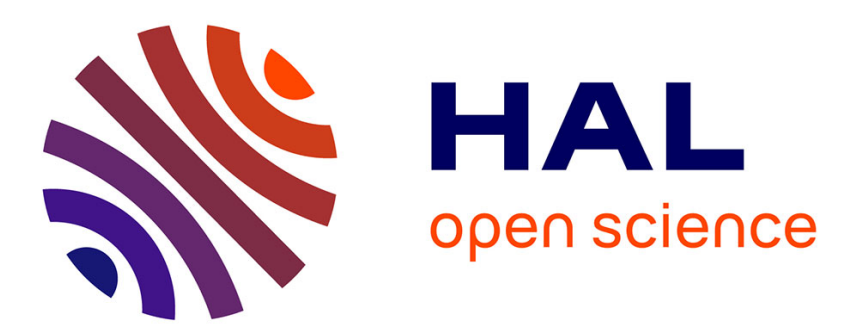

\title{
Intention in Action: A Pragmatic Approach to Criminal Characterisation in an Egyptian Context
}

\author{
Baudouin Dupret
}

\section{To cite this version:}

Baudouin Dupret. Intention in Action: A Pragmatic Approach to Criminal Characterisation in an Egyptian Context. Standing Trial: Law and the Person in the Modern Middle East (Dupret, ed., I.B. Tauris), 2004. hal-02614261

\section{HAL Id: hal-02614261 https://hal.science/hal-02614261}

Submitted on 20 May 2020

HAL is a multi-disciplinary open access archive for the deposit and dissemination of scientific research documents, whether they are published or not. The documents may come from teaching and research institutions in France or abroad, or from public or private research centers.
L'archive ouverte pluridisciplinaire HAL, est destinée au dépôt et à la diffusion de documents scientifiques de niveau recherche, publiés ou non, émanant des établissements d'enseignement et de recherche français ou étrangers, des laboratoires publics ou privés. 


\title{
Intention in Action:
}

\section{A Pragmatic Approach to Criminal Characterisation in an Egyptian Context}

\author{
Baudouin Dupret \\ CNRS-CEDEJ, Cairo
}

In criminal matters, intentionality constitutes one of the central criteria in the work of legal characterisation. This research undertakes to show how magistrates and, more particularly, public prosecutors organise their activity, in practice, around the establishment of this component of the crime. After having made a few preliminary remarks concerning the recourse to a pragmatic approach in the study of law, I shall give a summary sketch of the literature in the theory of law pertaining to this question. The essentially semantic nature of these approaches will be noted as they attempt to comprehend intention as a philosophical notion independent of the institutional context of its use. I shall then endeavour proposing a pragmatic approach in which intentionality is viewed as the result of interactions integrated in the judicial institutional context which obliges professional actors to orient themselves toward the production of a legally relevant decision. This leads me, in conclusion, to observe that lay actors adjust themselves to this constraining institutional context, influenced by inductive reasoning of professionals and by their own anticipation of the means which would enable them to obtain the most favourable or the least damaging solution for themselves from the place and the persons with whom they are confronted or simply the solution most conforming to the routine accomplishment of their work.

\section{Preliminary remarks: the production of legality}

The pragmatic study of the legal process which leads to the sanctioning of an intentional act, an act where wrong has been done to others, requires a few preliminary remarks of an epistemological and methodological nature. 
The use of ethno-methodology and conversational analysis and the reference made to them in the study of law entails an emphasis upon the difference existing between the recourse to legal material to obtain knowledge of interactional language and the analysis of legal procedure supported by an ethno-methodological and conversational process. As Rod Watson has observed, "some of the best ethnomethodology and conversation-analysis studies of law and legal reasoning come from analysts who do not regard themselves as having any special interest in "the law" as a sociological specialism but instead simply conceive of themselves, like Garfinkel, as doing generic ethnomethodology and conversation analysis: there is a real distinction of focus here". 1 The following contribution is meant to instrumentalise ethno-methodology and conversation analysis to achieve a better analytical examination of the legal process. However, no longer an end in itself, conversation analysis itself no longer suffices, authorising, at the same time, the reintroduction of other analytical perspectives provided, however, that any ironic attitude be renounced, any impending position by which the sociologist would substitute himself for the interactants in the enunciation of what they do in reality. This assumes, in the sociological study of law, that neither professional nor lay knowledge, nor the sociological and positive knowledge of law are dichotomised. Succinctly stated, it could be said that, in the matter of law, it would be wrong to view laypersons and professionals as "legal dopes". 2

A second remark pertains to methodological differences brought about by the existence of procedural differences. The interest in legal interactions is by no means indifferent to the context of Egyptian law which can be schematically linked to the civil law family. The formal procedure is, therefore, very distinct from that which is followed in the common law system. Thus, while Paul Drew can assert that, "in the adversarial Anglo-American criminal-judicial system, crossexamination is essentially hostile", ${ }^{3}$ it should be noted that, in the system of civil law, the very

\footnotetext{
${ }^{1}$ Personal communication, 18 December 1996.

2 To paraphrase a formula by Garfinkel enjoining that one not take people for "judgemental dopes" (Garfinkel, 1967, pp. 66-75).

${ }^{3}$ Drew 1992, p. 470.
} 
principle of cross-examination does not really exist. This difference in procedural organisation has major consequences for the forms of verbal expression and for its utilisation.

In criminal matters, the Egyptian legal system follows the inquisitorial procedure proper to laws of Romano-Germanic tradition. This means that the occurrences of an act likely to entail penal consequences is automatically transferred to the public prosecutor's office, the institution charged with conducting the inquiry and preliminary investigation of the case. In this context, the victim of the punishable act is removed from the case as party in the legal action and the public prosecutor takes his place. The victim is, therefore, only called upon as a witness. The public prosecutor, after having heard the different protagonists in the case, establishes the facts and gives a first decision as to admissibility. It is thus for him to consider the matter as closed or to hand it over to the court. In theory, the representative of the public prosecutor's office (substitute for the public prosecutor) provides a verbatim transcript of the depositions made before him by the different protagonists whom he has summoned to investigate the case. On that basis, he drafts a statement (which, when he hands it over to the court, is entitled "inventory of the elements of proof'). The court hears the speeches for the defence with this document as reference, submits the matter for decision by the bench and pronounces its judgement. According to the nature of the case, the court is composed of one or three judges. The court sessions are not transcribed. The ruling, on the other hand, is written.

The above leads to a third observation. The study of the process of the production of legality is closely dependent upon the very nature of the procedure followed before the judicial instances. In the case with which we are concerned, two particularly important points must be underscored: the essentially written nature of the legal process and the very particular organisation of the hearings conducted by the public prosecutor.

In criminal matters, the role of the advocates consists, above all, in structuring the account of the protagonist-cum-client so as to render it legally relevant. The low degree of interaction in 
this exercise should be noted. While the advocate can first be prevailed upon to ask a number of questions of his client in order to enable him to construct a relevant account - which entails reflexive interaction - he then, in a second instance, produces a general written and oral account, legally restructured to serve both to orient his client and to substitute himself for his client before the magistrate. It is only in a marginal way that the advocate will intervene during the interrogation of his client in order to rectify a point. It should also be noted that the sentence is not delivered in the Egyptian judicial system by a judge attended by a jury.

This difference in structure is essential in the analysis of the process of legalisation. Actually, it entails the complete adaptation of what has been established through conversation analysis such as applied in the process proper to common law. This assumes, among other things, that the study is directed towards specific materials which, until proof of the contrary, have not been considered in terms of conversationalist research and that the conclusions proper to the work on cross-examination and the jury are only quite indirectly utilised, to mention only two types of well-known research. In fact, in the Egyptian legal process, verbal interaction is, on the whole, rather minor. Sometimes, a specific question is addressed to the accused, to the victim or to a witness and sometimes, there is a request for a speech by the lawyer defence - and this, itself, is generally reduced to its simplest expression on account of the extreme overload of the courts (seldom fewer than 200 cases are taked up during one and the same session, sometimes over 1,000 are taken). Deliberations of courts and tribunals are generally done on the basis of a draft ruling drawn up by a magistrate and rarely discussed in detail among colleagues.

The substitute for the public prosecutor is directed by virtue of formal rules governing the organisation of his work to conduct an interrogation, the context of which is transcribed verbatim by his secretary. It is, however, important to note that matters generally do not proceed exactly in that manner. In most of the hearings which it was possible to attend, the interrogation took place in two stages. First of all, the substitute, after having confirmed the identities of the suspect, the 
victim or the witness, calls for a general account, beginning with a very broad question of the type: "What are the details of what you admit having done?". Having heard the account in its generality and without the latter having been transcribed, the substitute takes up the account, point for point, organising it around a series of questions which he is directed to pose by virtue of rules proper to his professional activity. The re-configuration of the account around legally relevant questions is a fundamental element in the process of legalisation. It is to be observed that the interactive character of these hearings is greater than at the previous (lawyer) and subsequent (judge) levels in the judicial sequence. Also to be noted is the absence at this stage, as at the others, of any "overhearing audience", ${ }^{4}$ that is, of a silent auditor to whom the interactants address themselves beyond their direct verbal exchange.

The different protagonists of the hearing do not interact in having to address themselves simultaneously to a silent auditor as is the case in a cross-examination which is directed at the jury. This remark can, however, be differentiated if the interaction is re-inscribed in the framework of the long sequence of the criminal proceedings. In fact, it can be assumed that the protagonists and, no doubt, the substitute for the public prosecutor more than those whom he interrogates, address themselves indirectly to the judge who, at a subsequent stage, will be called upon to take cognisance of the facts such as revealed in the inquiry report and to make a ruling on this basis. Perhaps, one should thus speak of an "overreading audience", that is, of a silent and absent reader to whom the interactants address themselves beyond this direct verbal exchange, an auditor, in other words, for whom the hearing is deferred in time.

A fourth observation pertains to the notion of context. The context sensitiveness assumed by the ethno-methodological and conversational study of the judicial sequence requires that it be re-situated in the overall context of the Egyptian legal process. This implies a consideration of the extra-verbal elements in the interaction. One can illustrate this point by way of example. In the

\footnotetext{
${ }^{4}$ Drew 1992; ibid., 1997.
} 
matter of drug trafficking, the police generally refer the matter to the substitutes of the public prosecutor, addressing a police report to them recording an infraction. It is widely known among members of the public prosecutor's office that this police report commonly relates the facts by following a standard scenario which leads to the establishment of the crime. For the police, it is not so much a matter of describing the facts as they have occurred as of producing an account which records the crime according to the rules of the genre. Thus, it is, above all, necessary that the account be devoid of the very frequent infringements of legality which, were they noted, would result in a legal flaw and in a nullification of the entire procedure. The hyper-contextuality to which one would be circumscribed out of concern for ethno-methodological and conversational orthodoxy would risk leading to an omission of the factors proper to a larger though still accountable context. In a word, it might be said that a contextualising context does not authorise neglect of the fact that the context is already contextualised.

One of the first consequences to be drawn from the introduction of the notion of contextualised context is to not limit the information from a given legal sequence to a single segment of this sequence, but, on the contrary, to extend it to the entire sequence in which the segment is inscribed. In other words, a punctual judicial operation must be considered as a segment in a long sequence.

From the perspective of the analysis of a single segment in the legal sequence $(1$ in the diagram), the interaction, in the first instance $a$, pits $\mathrm{Q}$ (the interrogator) against $\mathrm{R}$ (the respondent), the interrogator drawing up, in the second instance $b$, his report for the sake of its recipient $\mathrm{D}$. If, on the other hand, one takes up the idea of the "overreading audience" ( 2 in the diagram), the interaction $a$ is no longer binary but becomes ternary by introducing the silent auditor (A) of the verbal interaction into the interaction itself Q-R-(A). In a second instance $b$, Q also draws up his report for the sake of its recipient $\mathrm{D}$ who was, in the first instance $a$, the third party in the interaction $(\mathrm{D}=(\mathrm{A}))$. The same is the case for the interaction between the policeman 
and the accused. Because he must respect a certain number of rules of form, the policeman conducts his interrogation by pre-empting the objections which the substitute for the public prosecutor could make to him. In fact, the interaction with the third party of the interaction functions in the manner of the "absent third". Without physically participating in the interaction, the absent third closely conditions it.

This diagram would, of course, be more complex were it to relate to the legal sequence in its entirety: police interrogation, report to the substitute (discussion with the lawyer), interrogation conducted by the substitute, report to the court (pleas by the advocate) and deliberation of the court. It is, therefore, in our view, fundamental to account for all the interactants, whether physically present or not, in each segment of the long legal sequence.

A final remark concerns the utility of the notion of typification to which one turns in the study of the legal process. This notion is far from being solely the reserve of ethno-methodology and conversation analysis. Bernard Jackson, for example, proposes a model of law analysis in terms of narrative typifications. ${ }^{5}$ Setting out from the question of the comparison of factual situations with a collective image (for example, that of "acting like a thief"), he develops the idea of a paradigm at a distance from which are located the events which take place and which are evaluated by the different social actors. The collective image is, therefore, both the description of a typical action and the social evaluation of the performance. Comparison with the collective image in this way constitutes a transfer of modality.

This is what Bernard Jackson terms a "narrative typification of action", three characteristics of which can be distinguished:

${ }^{5}$ Jackson, 1995. 
- it does not produce demonstrable judgements of what relates or not to the collective image (it is not a definition in terms of necessary and sufficient conditions), but it produces judgements of relative similarity;

- such a typification is not a neutral description, but comprises a form of evaluation;

- certain typifications are characteristic of certain semiotic groups which are differentiated by the systems of signification (although they can, in part, be superimposed).

The narrative typifications quite evidently do not function mechanically, but, on the contrary, in a negotiated and interactionist manner. ${ }^{6}$ The law, whether a matter of rules, decisions or other indictments and speeches for the defence makes use of narrative models in an institutional frame. ${ }^{7}$ The legal decision, to take only this, thus becomes a procedure of comparison, more evaluative than constative, of concurrent narrative units, unit(s) of fact and unit(s) of rules.

From an even more pragmatic perspective of typification, Alfred Schutz proposed his general thesis of the reciprocity of perspectives which is founded on two idealisations: the interchangeability of points of view and the conformity of the system of relevance. The reflection operates by referring to already available types which are organised in schemas of experience and which are oriented around past experiences and consigned to the actor's stock of experience. ${ }^{8}$ Along the lines of Schutz, ethno-methodologists have been sensitive to the social generativeness of categories. Thus, for Garfinkel, categories are both principles in the construction of reality and emerging objective realities. This is most particularly evident in his analysis of the case of Agnes, a transsexual. ${ }^{9}$

\footnotetext{
${ }^{6}$ Jackson 1995, pp. 150-151.

${ }^{7}$ Jackson 1998, p. 101.

${ }^{8}$ Schutz, 1990.

${ }^{9}$ Garfinkel, 1967.
} 
The realisation of categories, from this perspective, is oriented and constrained by a schema of naturalness and normality, that of the "natural and normal woman" in this case. This schema provides the rules and methods of configuration of conduct, dispositions and recognisable attitudes such as realisations of the category "natural and normal woman". It consists of a system of conventional beliefs: persons subscribe to definitions held to be self-evident because they are legitimate; they generally take the form of background expectations of current life which they use as reference points to configure their conduct and to constitute, by interpretation, that which assumes for them the "appearances of familiar events". Sacks, for his part, developed a few essential insights to explore the operating value of categories in the sequential organisation of the course of action and in the construction of the observability, analysability and describability of social phenomena.

These insights can be summarised in four points: the regulated character of the selection of categories in the identification of persons, objects or events and the normative nature of the categories (collections of rights and duties); the supportive role played by the categories in the organisation and actualisation of common-sense knowledge of the social world; the sequential and temporal organisation of the courses of action (the selection of categories to define a situation makes the manner of treatment of this situation accessible just as the co-selection of categories ensures the congruence of the order of relevance necessary for the inter-comprehension and coordination of the action) and the capacity to make the phenomena visible and observable. ${ }^{10}$

\section{Intentionality: a classic perspective}

Preliminary remarks having been made, a detour must now be made with what will be described as a classic approach to the question of intention in legal theory and philosophy so as to

\footnotetext{
${ }^{10}$ Watson, 1994.
} 
be in a position to put this approach in perspective with the pragmatic process which is proposed if not as an alternative, then at least as an indispensable complement.

The study by Mauss of the notion of the person ${ }^{11}$ can conveniently serve as a point from which to begin such a classic description of intention in law. Mauss describes a broad evolutionary movement from a simple masquerade to the mask, from a personage to a person, a name, an individual, from the latter to a being with metaphysical and moral value, from a moral conscience to a sacred being and from that sacred being to a fundamental form of thought and action which would result in this fundamental category of contemporary understanding: the person.

It is from this perspective that a few recurrent notions of Kantian and Freudian discourse such as autonomy, liberty, will, conscience and intention are classically designated as markers of the modern conception of the person. The will, defined as the "faculty to freely determine to act or to abstain", constitutes, along with autonomy, one of the cornerstones of modern philosophy and epistemology. According to Kantian thinking, the subject has become a causal principle of a certain force termed action or intentional process. "The subject, the Kantian "cogito", is an autonomous instance ascribing a certain objectivity to objects in the world: objects as such, only becoming knowable in terms of the very subject which gives them a certain meaning which is never determined once and for all in itself, but which is always an expression of the intentionality of the subject in its actions and interactions". ${ }^{12}$

Liberty is also classically associated with will. "The human being can only judge what is proper through the use of the faculty called will for the idea of will assumes the existence of other faculties through which the will can express itself". ${ }^{13}$ The legal principle of the autonomy of will, a veritable basis of the law of contract, probably best expresses the importance of this

\footnotetext{
${ }^{11}$ Mauss, 1985.

${ }^{12}$ Stockinger 1993, p. 48.
} 
philosophical concept in law. Will, autonomy, liberty and intentionality thus form the very foundations of the philosophical economy of modern law and one immediately perceives all the implications which the concept of the subject acting freely and autonomously can have in terms of responsibility, imputation, premeditation, decision or judgement, all notions which are very much seen to be present if only one gives a quick look at the many codes of law.

The place occupied by responsibility in the philosophy of law originates in the Kantian philosophy of causality and imputation by virtue of which one must consider oneself as the unique and ultimate point of what happens to oneself with the notion of fault as the point of articulation. While one cannot fail to observe at which point the theory of responsibility underwent a very considerable evolution in the course of the twentieth century which not only saw it being substituted for a principle of solidarity in certain areas, but led to its break-up in other areas (for example, with the notion of hazard in labour law), also marking the passage from a philosophy of individual fault to a philosophy of collective reparation, ${ }^{14}$ it is nevertheless important to note that this extension in space and prolongation in time of the legal philosophy of responsibility does not occur in the sense of a de-individuation, but indeed in that of a reinforcement of the exigency of forethought and of the collectivisation of reparation. It is, in fact, not only a question of the imputation of fault, but also, anteriorly, of exigency of precaution and prudence and, posteriorly, of assumption of responsibility for the potential effects of the acts of each person.

Very interesting developments have been proposed by Herbert Hart regarding the questions of responsibility, causality and intentionality, particularly, in his Causation in the Law (1985) and

\footnotetext{
${ }^{13}$ Pufendorf quoted in Arnaud 1993, p. 345.

14 One speaks of the crisis of responsibility "with, as a starting point, a shift of accent formerly placed on the presumed author of the wrong but today preferably on the victim whom the wrong suffered places in a position to demand redress" (Ricœur, 1995, p. 58), with the passage "from an individual management of fault to a socialised management of risk" (Engel, 1993). Ricœur stresses the enormous paradox of a "society which speaks of solidarity only out of concern to
} 
Punishment and Responsibility (1968). In both works, the author closely examines legal reasoning and views it from the perspective of common sense. By briefly presenting Hart's demonstration, I believe that it is possible to identify a problem. The means that he employs to affirm the meaning assumed by certain notions in law and in common sense and the manner in which one ties up with the other do not, however, receive an entirely satisfying response. It is precisely at this level that the pragmatic perspective can cast new light on the matter.

The problem regarding intention, the only problem to concern us here, is in part subsumed, at least in the philosophy of law, under the broader question of causality and its relation to will. Intentionality is, in effect, a property of the cause of harm which is necessary to establish criminal responsibility in a number of important crimes. In other words, it is because the activation of the trigger (cause) is wilful (intention) that the death of the victim is defined as voluntary homicide and sentenced as such. But again, intention is the moral quality of a physical act which has caused a certain harm. This does not mean that contemporary criminal law necessarily assumes culpable intention for all crimes. The complete theory of recklessness is there to affirm that the law demands the presence of a positive (will) or negative (lack of foresight) mental element.

Responsibility thus involves "a minimum volitional and cognitive involvement, minimum volitional involvement being that his conduct would be an act (that is, an intentional corporeal movement and not a merely suffered movement, the effect of some physiological mechanism or of an external cause such as a physical force exerted by an other), minimal cognitive involvement being that the agent would be aware of what he does. (...This involvement) is minimum in the sense that it is not necessary that one acted willingly, that one subscribed to one's act or that one had desired or intended the consequences of one's act, in order to be responsible for it. One is, therefore, responsible for acts carried out under threat because, although it is true that in such

electively reinforce a philosophy of risk" and "the vindictive search for the culprit (which) is 
cases, one acts unwillingly, one acts despite everything intentionally and with a precise aim which is to avoid that the other carries out the harm which threatens us."15

Questions regarding causality appear at all levels of the law. Generally speaking, the question with which the courts are most often confronted is to know if a human act or omission caused any tort. In the domain of criminal law, to which we limit ourselves here, the causal relation between the action of the accused and the specific tort which was suffered must be established so as to estbalish the responsibility. Hart and Honore show how, "as in tort, so in criminal law, courts have often limited responsibility by appealing to the causal distinctions embedded in ordinary thought with their emphasis on voluntary interventions and abnormal or coincidental events as factors negativing responsibility". ${ }^{16}$ It is thus the moral nature of the cause which determines the criminal responsibility and the punishment of the crime. This is again found in the utilisation of legal standards in the matter of error or ignorance as that of "the wise and prudent man"; it is according to what one would have done in similar circumstances that one evaluates the accused conduct.

Most systems of law distinguish, in the definition of crime and its punishment, as to whether or not it is the product of a particular mental state disposing the perpetrator to the crime. In other words, intention is introduced as the determining principle of criminal responsibility and in relation to the severity of the punishment. Actually, criminal responsibility is first linked to the fact that the person has committed a crime and, second, that the person carried it out in a certain frame of mind or of will. The question of this mental state is generally raised to two levels, that of culpability and that of the evaluation of the sanction. At the level of culpability, the establishment of intention is generally sufficient, above all, for important crimes (although there are some

equivalent to an instillation of guilt in the identified authors of the wrong" (Ricœur, 1995, p. 59).

${ }_{16}^{15}$ Neuberg, in Canto-Sperber 1996, $\mathbf{v}^{\circ}$ "responsabilité".

${ }^{16}$ Hart and Honoré, 1985, p. 325. 
exceptions). At the level of sanction, the character of intention which is established influences the degree of punishment.

"The concept which legal theorists speak of and define as intention diverges from its counterpart in ordinary use at certain points which are of immediate interest to the philosophy of punishment". ${ }^{17}$ It is first appropriate to note the existence of a rich vocabulary which, while always accounting for the concept, nevertheless provides it with nuances: intentionally, maliciously, wilfully and recklessly are so many words used in legal English to express slightly different definitions of intention. Nevertheless, for Hart it is possible to distinguish what, in law, corresponds to intention. It is a matter of three interdependent parts which can be presented as “intentionally doing something", "doing something with a further intention" and "bare intention". In the latter case, it is the sole intention of doing something without anything being done to realise the intention in question. This hypothesis is not taken up as such in criminal law, contrary to civil law. In the second case - to do something with a further intention - one can take the example of man who enters the house of another at night.

Here, the question does not bear so much on the intention of entering the house as on the further intention of stealing something. If yes, the man would be found guilty of burglary, even though he may not have stolen anything. Numerous crimes are defined in terms of further intention such as "wounding with intent to kill". Finally, in the first case - intentionally doing something - one can take the example of a man who shot at another with a firearm and wounded or killed him. To the question as to whether he intentionally wounded him, the response will be that the physical movement of the body which led the finger to press the trigger expresses, until proven otherwise, a murderous intention, proof to the contrary eventually showing that he had thought the weapon not loaded or that he had not seen his victim at the moment that he fired.

\footnotetext{
${ }^{17}$ Hart, 1968, pp. 116-117.
} 
Apart from the element of volition, the intervention of three other factors will be noted: a physical element (the movement of the body), the result and the circumstances.

The combination of all these elements makes it possible to observe one of the points upon which legal theory and common sense are opposed. In effect, a man will be considered guilty if the prejudicial consequences were foreseeable by him or if he thought that they could result from his wilful act, even if the consequences as such were not desired. In other words, "The law therefore does not require in such cases that the outcome should have been something intended in the sense that the accused set out to achieve it, either as a means or an end, and here the law diverges from what is ordinarily meant by expressions like 'he intentionally killed those men"'. ${ }^{18}$ Actually, a result simply foreseen, but not intended, is generally not considered, apart from the law, as intentional. Generally, because there also exist situations where action and result are at this point connected such that it would appear absurd to say that an individual could act in a certain manner without intending that the action lead to this result (for example, someone striking a crystal vase with a hammer even should he do so with the aim of hearing the sound of metal against the crystal where common sense will consider that he broke the vase intentionally).

Following Bentham and Austin, legal philosophy has classically distinguished oblique intention which corresponds to the foresight alone of the consequences and direct intention in which consequences are an end conceived to be realised. The law condemns the author of an act, the intention of which was oblique, whereas common sense will consider that he has not acted intentionally. Hart gives the example of a man who, considering himself to be an execrable shot, shoots to kill and, contrary to his expectations, hits the target. In law, the man is guilty of murder. This is, no doubt, explained by the fact that in the two cases (direct and oblique intention), the author of the act is considered to have control over the alternatives open to him (to shoot or not to shoot). However, it will be noted that the English courts make a distinction between direct

${ }^{18}$ Hart, 1968, p. 120. 
intention and oblique intention in cases of ulterior intent. In this case, it is pertinent to demonstrate that the accused considered the result of his action as an end or as the means to achieve that end. In other words, even when the bare intention is not punishable as such, jurisprudence punishes as an attempt the fact of doing something which is not itself a tort if it is carried out with the further intention of committing a crime.

In short, it should be noted that "it is [the] principle of the autonomy of the individual which appears to be the point of convergence of our judgements as to responsibility. The fact of linking responsibility either to the wilful and cognitive involvement of the agent or to his ability, in principle, to attain a certain level of prudence and of reflection in his social interactions is explained by a fundamental decision in our system of responsibility in favour of the individual who is master of his choices, able to orient his conduct in conformity or disagreement with a system of norms." 19

That, briefly presented, is where the philosophical and analytical study of the notion of intention results. To us, this appears to be both much and little. Much, in the sense that the different parameters of representation of intentionality are broken up and analysed in detail to reveal most of the possible scenarios. It is, however, little insofar as the common sense of intention is only constructed on the basis of hypotheses founded on the presumed ordinary use of words whereas its legal concept is conceived only on the basis of a reading of the jurisprudence independent of any examination of the practical construction of the meaning in the different stages of the legal procedure. I should now like to attempt to show that the conceptions of intentionality do not correspond to an a priori definable semantic field outside the context of their interactional implementation. In other words, if Hart raises in this matter a number of perfectly relevant questions, he cannot give them an entirely satisfying response in his treatment of them. It is, in fact, a matter of recognising the contingent, contextual and normative nature of intention

\footnotetext{
${ }^{19}$ Neuberg, in Canto-Sperber 1996, vo "responsibilité".
} 
which is thoroughly constructed, utilised, reproduced and transformed by people in their daily interactions.

\section{Intentionality: a pragmatic approach}

Rather than considering that the actors find themselves subsumed in a context of action for which learned and incorporated rules are applicable and rather than analysing, consequently, the actions as if they were guided or caused by these rules, I propose adopting an approach which considers norms and rules as maxims for conduct. ${ }^{20}$ As Hart himself underscores, when speaking of the rule of law: "Particular fact-situations do not await us already marked off from each other, and labelled as instances of the general rule, the application of which is in question; nor can the rule itself step forward to claim its own instances. (...) Canons of 'interpretation' cannot eliminate, though they can diminish, these uncertainties; for these canons are themselves general rules for the use of language, and make use of general terms which themselves require interpretation. They cannot, any more than other rules, provide for their own interpretation." ${ }^{21}$ In other words, "legal rules cover an indefinite range of contingent, concrete possibilities. The rules must, in short, be applied, and to specific configurations of circumstances which may never be identical. (...) [T]he precedent having been established, there must still be a judgement as to whether the next occasion is sufficiently similar to fall within the scope of the prior judgement."22 This can be termed the indexical and reflexive nature of normative phenomena, that is to say, the tendency of events to point towards the norms to which reference is made and towards the signification which these same norms receive through the fact of their implementation in the course of action.

\footnotetext{
${ }^{20}$ Wittgenstein, 1989, § 202.

${ }^{21}$ Hart, 1961, p. 123.

${ }^{22}$ Heritage, 1984, pp. 121-122.
} 
To follow a rule can be understood as a typifying practice. In Husserl, one notes the existence of a foreknowledge typical of things which operates before any predicative judgement. Expressed in sociological terms, that means that people immediately grasp things, events and persons as belonging to a species with its typical properties within "a horizon of familiarity and pre-acquaintanceship which is, as such, just taken for granted until further notice as the unquestioned, though at any time questionable stock of knowledge at hand". ${ }^{23}$ This means that, “events have 'normal patterns' and 'usual causes' of occurrence that can be relied upon". ${ }^{24}$ These schemas are certainly vague, but the actors first display their perception of the normality of events and it is only in incongruous situations that they seek explanations for the threat weighing upon normality. It is in this sense that persons are (made) morally responsible for any breach of what is perceived as the normal course of events.

Legal categories do not elude the schema of naturalness and normality. Thus, the idea of the normal person constitutes one of the points of reference for practical legal reasoning with, in consequence, the ideas of volition and cognition attached to it. As such, the conscious and intentional person, far from being an abstract and inaccessible category, is publicly constituted with the help of the methodical deployment of public, that is, linguistic resources in social interaction. ${ }^{25}$ The realisation of this category of person is, from this perspective, oriented and circumscribed by the schema of the natural and normal person, conscious and endowed with an autonomous will. This background is constantly mobilised even though it remains largely unexplained and loosely defined. That being so, to be defined as a person largely depends on the capacity of persons to present a normal appearance and to expect to be treated by others on this basis. As Harvey Sacks noted, "In public places persons are required to use the appearances others present as grounds for treating them. Persons using public spaces are concurrently

\footnotetext{
${ }^{23}$ Schutz, 1990, p. 7.

${ }^{24}$ Heritage, 1984, p. 77.

${ }^{25}$ Watson, 1998, p. 213.
} 
expected by others to present appearances which can be readily so used, and expect others to treat their own appearances at face value." 26

Thus, one is not confronted with persons naturally conscious and endowed with will, but with the consciousness and will of the naturalised person in such a manner that one can evaluate the conformity and will of each occurrence and of the general type with all the rights and duties belonging to this type - which conversation analysts term "membership categorsation device".

Let us take a concrete example from the Egyptian legal context. The following excerpt is the account of a girl alleged to have been the victim of an attempted rape, redefined by the public prosecutor as breach of modesty (hitk'ird).

\section{1.}

Question of the substitute: What took place?

Response of the victim: I was on the street that day...when I met those two there... and they said to me "come with us" and they made me get into a taxi... and they went behind the Arsenal.

Q: What was their intention in acting like that?

R: They told me "Don't worry, we are going to drink tea together".

Q: Why did you not call for help when they took you...?

R: I tried to scream and I rolled on the ground, but the street was empty.

Q: What is the number of the taxi in which they took you?

R: I don't know, this happened on the street.

Q: Why did you not ask the taxi driver for help?

R: The driver was afraid of them and he did what they told him to do.

Q: What was their intention in taking you with them?

R: I think they wanted to attempt (an attack) on my virtue, otherwise they would not have taken me to that place.

${ }^{26}$ Sacks, 1972, p. 281. 
Q: Did you know them before?

R: No.

Q: Do you have anything else to say?

R: No.

(Case n ${ }^{\circ} 5471,1977$, Mahram Bey, Alexandria)

This excerpt illustrates several interesting points as regards the question of intentionality. It will be noted that the act is always presented as having a motivation. Here, fear and trust are combined in such a way as to motivate the girl's consent to go with the two boys (Q: "What was their intention in acting like that?" R: "They told me 'Don't worry, we are going to drink tea together"”) and to not refuse to get into the taxi (“...and they told me to get into the taxi"). On the other hand, the substitute is always seeking an individual act ("Why did you not call for help when they took you...?”) which was motivated (“Why did you not ask the taxi driver for help?”) and had a purpose ("What was their intention in taking you with them?"). This should be underscored insofar as it shows how the substitute constructs the interrogation with practical ends, that is, in anticipation of the different stages he will have to cross centred around legally relevant questions of the type "who did what to which purpose".

The cases of minors and of the mentally deficient prove to be particularly interesting in the pragmatic study of the notion of intention on at least two levels. First, on the level of the intention or consent of the victim. Criminal law establishes a presumption of the absence of consent in sexual relations on the part of the minor. Consequently, the substitute directs his action towards the establishment of minority. The first example below is taken from a case of abduction and rape of a minor, and the second from a case of attempted rape of a mentally deficient minor.

\section{2.}

Q: What are the distinctive features of the missing girl and what is her age? 
R: Her name is Thanâ' Husayn Qâsim, she is eight years old, she is fair-skinned and has blond hair, she is wearing jeans and a yellow tee-shirt.

(Case $n^{0} 5719,1996$, Rûd al-Farag, Cairo)

\section{3.}

Q: What is his approximate age?

$\mathrm{R}$ : He is seventeen or eighteen years old and has been mentally retarded since his birth.

(Case $n^{\circ} 7158$, Sâhil, Cairo)

In both cases, however, the substitute attempts to go beyond these presumptions to discover the intention of the victim - I shall later return to the intentions of the aggressor and of the witness. In the first case, he directs several questions to the parents of the girl so as to determine a background upon which to construct a plausible and legally definable scenario. The explanations given by the parent of the victim clearly reveal that the latter is aware of the inferential significance of his responses.

4.

Q: Does the missing girl suffer from a psychological or nervous illness?

R: No, she is well (...)

Q: Has she already disappeared before?

R: No (..)

Q: Which places does the missing girl frequent?

$\mathrm{R}$ : None, she played in the street (...)

(Case $n^{\circ} 5719,1996$, Rûd al-Farag, Cairo)

In the second case, it is a question, even though the mental retardation of the victim does not constitute an aggravating circumstance in the case of breach of modesty to demonstrate that there could not have been a consent by the victim as the latter is mentally deficient. 


\section{5.}

Q: Based on the facts to which you were party, was your son in agreement with this assault or did he resist?

$\mathrm{R}$ : My son is mentally retarded and he knows nothing and remained silent.

(Case n ${ }^{0} 7158,1993$, Sâhil, Cairo)

The intention of the aggressor is also sought in such a manner so as to be able to define the act in accordance with the categories of law. The aggressor, whose responses are clearly oriented according to the inferential significance which he knows can be attributed to them, can adopt different attitudes. In the first case, he seems to shift the intention towards an outside agency.

\section{6.}

Q: What is the context of the discussion which took place between yourself and the victim?

$\mathrm{R}$ : The devil sometimes rises in me and I said to myself: "I should amuse myself with her in whatever way so that she comes to my place with me so that I sleep with her" and I said to her ...

(Case n ${ }^{\circ} 5719,1996$, Rûd al-Farag, Cairo)

In the second case, the aggressor has recourse to a strategy to avoid detrimental inferences.

\section{7.}

Q: At first sight, is this a question of a person who can understand?

R: He speaks in a jerky manner.

Q: Is he mentally retarded?

R: I don't know.

Q: You have known the victim since 1978 and you do not know if he is mentally retarded or not, notwithstanding the fact that it is obvious that he is mentally retarded?

R: I don't know.

(Case $n^{\circ} 7158,1993$, Sâhil, Cairo) 
The intentionality of the witness can also be questioned as the following excerpt shows.

\section{8.}

Q: Do you suspect that her disappearance is criminal?

R: No.

Q: What is your purpose in making this deposition?

R: To take the steps necessary to find her.

(Case n ${ }^{\circ} 5719,1996$, Rûd al-Farag, Cairo)

This question may appear to be quite absurd. However, it reveals that the substitute does not want to neglect any hypothesis, including the possibility of the involvement of the parent who comes to make the deposition. Raising this question, he solicits a response, the possible incongruity of which would direct him to explore an alternative track. This explanation is confirmed during a later interrogation at which time the substitute raises the question of the delay made in informing the police.

\section{9.}

Q: What do you know about her disappearance from the house on 11 October 1996 until she was found?

R: I don't know where she was, but I heard a child from the corner say that a strange man had called her while she was playing with them and said, "bring me soap from the grocer" and gave her money and when she returned, he gave her twenty-five piastres and he took her into the house where we found her.

\section{(...)}

Q: When precisely were you given this information?

R: I know all that from the little boy since the day that my daughter disappeared from the house.

Q: How do you explain not having made a deposition about all that until now? 
R: I told myself, "those are the words of a child" and we were not certain.

(Case nº 5719, 1996, Rûd al-Farag, Cairo)

It indeed appears that, in the criminal process, the substitute would be seeking a legally relevant definition which he obtains by producing a narration of events centred around the accounts of the persons interrogated and which he reconstructs to the purpose of their future use in the legal process. The accounts of the persons are thus solicited to then be sifted for possible incongruities with an alternative schema in which normality would appear between the lines as implicitly suggested by the substitute. ${ }^{27}$

This pragmatic exploration of intentionality cannot be continued without introducing the fundamental question as to the context in which it is solicited, identified and instrumentalised for subsequent judicial ends. It clearly emerges from the preceding examples that the interactants, the members of the group of participants in the legal interaction, manifestly orient themselves according to the particular context of this interaction. Generally, it can be established that statements and acts are shaped by the context which, at the same time, they renew. They are shaped by the context in the sense that statement and act must be referred to the activity immediately preceding them and to the larger environment in which this sequence takes place. They renew it in the sense that statement and act are, at the same time, results of a previous sequence and the basis of subsequent sequences. ${ }^{28}$

The legal context has, in particular, that it is institutional which gives it three distinct characteristics: the discourse in this context is conditioned by its orientation towards a goal; the interaction can be subject to certain particular constraints and the discourse can be associated

27 Regarding this "procedure in incongruity", cf. Matoesian 1997; Dupret, 2003. Cf. also Moerman, 1987, p. 61: "The defendant is accused of having killed for hire, a form of murder rather common in northern Thailand at the time of fieldwork. A usual defence in such case is that the accused is not the kind of person who would do such a thing, that he comes from a good family, that he does not need money".

${ }^{28}$ Drew and Heritage, 1992, p. 18. 
with inferential frames and procedures. In the first place, "both lay and professional participants generally show an orientation to institutional tasks or functions in the design of their conduct, most obviously by the kinds of goals they pursue", ${ }^{29}$ even though such an orientation could change according to local contingencies of interaction and locally defined status of the interactants. In the second place, the conduct is often shaped in an institutional environment by reference to goal-oriented constraints. Moreover, in view of specific contexts such as in the courtroom, it appears that "participants shape their conduct by reference to powerful and legally enforceable constraints which impart a distinctly 'formal' character to the interaction". ${ }^{30}$ In the third place, inferences and implications tend to be specifically developed in institutional interaction.

All these characteristics are not without consequence on the system of turns at speaking, the attitude of the interactants, the range of institutional options, the proceduralisation of interaction, the institutionalisation of the incongruity mechanism, the lexical choice, the organisation of the sequence, the standardisation of the schemas of interaction and of professional practices and the asymmetric organisation of interaction. In the legal frame, this asymmetry is particularly to be found in the configuration of exchange around the system of questions and responses and in the different strata of knowledge available to and used by laymen and professionals. In addition, the strongly routinised nature of professional action should be noted. This all means, to return to intentionality, that attention must be given to the characterisations which persons ascribe to each other in real contexts and not to the decontextualised presumptions as to attitude and membership. The institutional frame assigns roles and types of intentions to persons belonging to it, making a number of inferences possible.

The fact that the parties are oriented towards the institutional framework and its procedural implications (the trial) means that they are aware of questions concerning personal involvement

${ }^{29}$ Drew and Heritage, 1992, p. 22. 
and intentions. This research intends to show that the definition of intention in inferred from concrete interactional circumstances and information and is not necessarily deduced from theoretical treatises. In the case of intention, as in other instances, representations concerning the profound nature of conscience are not at work, but rather it is the very practical and concrete orientation of persons towards a very practical and concrete result in an interactional situation inscribed in a legal frame and on the basis of discourse and accounts from which every protagonist understands to draw a certain number of inferences. The latter operate as the basis of an interplay of congruence and incongruity between the typification considered to be normal and the factual accounts. Every protagonist is involved in producing a sense of normality and an account, the facts of which are in line with or demarcate this normality. This obtains in the case of the accused as well of other protagonists: victim, witness and substitute, all of whom tend to produce an account articulating the intentional or non-intentional character of the act and the inferences which follow therefrom. Without entering into details, I give a number of typical excerpts below recapitulating a few variations of intention in actuality.

I have already mentioned the case of the girl who was allegedly the victim of an attempted rape.

\section{0.}

Q: What took place?

R: I was on the street that day...when I met those two there... and they said to me "come with us" and they made me get into a taxi... and they went behind the Arsenal.

Q: What was their intention in acting like that?

R: They told me "Don't worry, we are going to drink tea together".

$(\ldots)$

Q: What was their intention in taking you with them?

${ }^{30}$ Drew and Heritage, 1992, p. 23. 
R: I think they wanted to attempt (an attack) on my virtue, otherwise they would not have taken me to that place.

\section{$(\ldots)$}

Q: Did you know them before?

R: No.

Q: Do you have anything else to say?

R: No.

(Case $n^{0}$ 5471, 1977, Mahram Bey, Alexandria)

This excerpt clearly shows how the victim organises her words around the idea of the normal conduct which she had adopted (walking in the street). Conversely, the conduct of the accused is at odds and stands in contrast (they went behind the Arsenal), even if it did not at first appear as such - the victim thus provides the elements which make it possible to explain that she was deceived (we will go drink tea). The substitute participates in the production of this effect of incongruity by raising the question as to whether the girl knew her aggressors before. Had she known them, her having left with them to drink tea would not have been surprising. Had she not known them, it would, on the contrary, be clearly more surprising and it is no doubt at this level that the idea of force usefully arose (they made me get into a taxi). For the victim, her own intention is congruent with a normal schema which she constructed with her own words. Conversely, the same victim underscores the incongruity of the intention of the accused with the same normal schema, in other words, criminal intention and abnormality in terms of the schema correspond to each other.

Now, turning to the accused, I reproduce an excerpt of the interrogation conducted by the president of the criminal court in a case in which the individual accused of murder pleads the fact that he was under the sway of evil spirits at the time of the act. 


\section{1.}

Q: Why did you take Qiddisa Tumas with you on the $10^{\text {th }}$ of Ramadan?

R: At the request of the victim, because there was no one who knew that she had an evil spirit and she feared that people would find out.

Q: How did you know that the victim was possessed by the devil or evil spirits?

R: She told me that she had headaches and hallucinations and I told her: "You are possessed by a devil".

\section{(...)}

Q: What happened to the victim when you prayed for her?

$\mathrm{R}$ : I felt feverish and in a terrible state of confusion and I lifted the veil she... and she did not respond and I did not know what to do.

Q: Did you undertake to move the body by yourself to the place at the bottom of the building?

R: There was no one to help me and I do not know how I lifted her.

Q: The pathologist established that the victim was in undergarments.

R: She was wearing all her clothes.

$(\ldots)$

Q: In what position did you place her in the hole?

R: I know nothing.

(...)

Q: Was there anyone with you during the prayer for the victim?

R: No, there was no one there during the prayer and she died by herself.

Q: Was the victim wearing gold jewellery on her ears and on her breast?

R: No.

Q: The victim was wearing gold jewellery on her ears and breast.

R: She was not wearing jewellery. 
$(\ldots)$

Q: How long did you know the victim?

R: My sister's daughter married her son.

Q: Were there other relatives?

R: No, there were no other relatives than the immediate family.

$(\ldots)$

Q: Have you ever prayed for anyone before and expelled evil spirits from them?

R: Yes.

Q: The daughter of the victim says that she was sane.

R: No, she never spoke with anyone else.

Q: Was there any financial compensation in exchange for that?

R: No, it was crazy.

Q: The pathologist says that you strangled her.

R: No, she died naturally.

(Criminal Court of Cairo, Case $\mathrm{n}^{\mathrm{O}} 2783,1997$ )

This excerpt, somewhat long but certainly worthwhile, points out a great number of details about intention. Regarding motivation and initiative (I took the victim at her request because she did not want anyone to know she was possessed by the devil), it is observed that the accused attempts to show an absence of personal interest in initiating the act without, for all that, jeopardising his own credibility. ${ }^{31}$ The question of agency is also fundamental (I felt feverish and in a terrible state of confusion and I lifted the veil she... and she did not respond and I did not know what to do). The accused clearly attempts to efface his personal agency in the course of the act while not appearing to be mentally deranged and not jeopardising his credibility in the account that he gave of the action of the spirits. In other words, the accused does his utmost to

${ }^{31}$ Cf. Komter, 1998. 
minimise his active participation in the events and by formulating an alternative version involving the participation of a third actor.

In doing this, he affirms common sense regarding the morality of certain matters (for example, to kill is immoral), but he also avoids the negative inferences which could be drawn on the subject of his own moral qualities. He keeps himself in the background of the scene which allows him to claim to be neither personally responsible nor mentally irresponsible. ${ }^{32}$ The accused also attempts to give excuses for the acts committed (There was no one to help me carry the body and I do not know how I lifted it) by invoking the action of an outside constraint effacing his personal and intentional agency. Finally, one will note the interwoven relationship of questions of personal agency and normality (There was no one there during the prayer and she died alone, she died naturally).

Each situation is characterised by what is considered to be the normal conduct of the involved actors. In the case of death, the normal and natural character of matters is defined according to the absence of human agency in its cause. The abnormal death is that provoked by the intervention of an outside human agent. For that reason, the death of someone which is due to the action of evil spirits cannot be considered as abnormal as it does not result from the action of a human agent. On the other hand, suicide is abnormal because it is the result of the victim's own agency. Generally speaking, the accused is thus in the situation of having to show that he did not have an intention to do something, that he did not have the inclination to carry out what the normal typification negatively evaluates or that his intention could be explained so as to excuse himself. In so doing, he struggles in a net of insurmountable dilemmas. Each time, it is important to discern the complexity of the relation which the accused has with the object of the offence around which his punishable intention revolves.

${ }^{32}$ Cf. Komter, 1998. 
The witness is also involved in the contingent production of a notion of intentionality. The latter, of course, bears on the victim and the accused, but also on the witness. By way of illustration, I shall again consider one of the cases previously mentioned and examine the testimony of the father of the victim.

\section{2.}

Q: For what reason did she leave the house the last time and did someone accompany her?

R: She left to play in the building because it was her holiday and she played with the children in the building.

Q: Did the child suffer from any psychological or nervous illness?

R: No, she was very sane and very lively.

Q: Was she wearing anything of value?

R: No, we are poor, God decides.

Q: Had signs of her womanhood appeared?

R: No, she was a little girl but fair-skinned and with beautiful blond hair.

Q: Had she already disappeared from home previously?

R: No, she was always a good girl.

Q: What was the nature of her relationship with the family? Did she have differences with anyone?

R: No, she was a good girl as far as we and everyone were concerned and no one ever complained about her.

Q: Do you have differences with anyone?

R: No, I am a peaceful man and I do not have problems with anyone.

Q: Who was this person exactly and what was your daughter's relationship to him?

R: I do not know who it was and the girl also did not know him because the boy said he was a stranger to the quarter. 
$(\ldots)$

Q: Do you suspect that her death was criminal?

R: Yes, of course.

Q: Do you suspect someone of having perpetrated this act?

R: God will triumph over whomever did it.

(Case nº 5719, 1996, Rûd al-Farag, Cairo)

The witness gives versions of intention which are closely dependent on his relation to the facts and to the main actors involved in them. This relationship is, above all, marked by exteriority. The witness is not a main protagonist and, as such, his personal agency is not, at least not directly in question. As noted by Renaud Dulong, the witness plays an auxiliary role and his person and affects are not of interest. ${ }^{33}$ When he attests to the traits, characteristics, acts and gestures of a person, the witness produces a report of his conduct, his credibility and, consequently, of his intentions. This is directly oriented towards a practical goal of accentuating figures and situations, of the typifications to which they are subject and, consequently, of possible qualifications of the established acts. Thus, in the example given above, the witness gives a description accentuating the normality and qualities of the child (She was a good girl, sane and lively, still a child who wore nothing of value). In so doing, he establishes a marked contrast between this normality and what took place upon which background the death of his daughter necessarily appears to belong to the category of odious crimes and, by the same token, to morally qualify the presumed author. This becomes even more explicit during the testimony of the mother.

\section{3.}

Q: Do you have anything else to say?

R: Yes, I want to say that you should have that fellow hanged.

\footnotetext{
${ }^{33}$ Dulong, 1998, p. 41.
} 
(Case ${ }^{\circ}$ 5719, 1996, Rûd al-Farag, Cairo)

It will also be noted that an ethical quality which is at the basis of the veracity of his testimony is also demanded of the witness. ${ }^{34}$ In other words, the relationship of the witness to the subject of his testimony is examined so as to judge the quality of his testimony. The witness must, therefore, also orient his testimony so as to avoid detrimental moral implications which the latter could entail. Here, the witness must account for his own intentionality. That could consist in underscoring the typical and normal nature of his situation regarding the victim by having recourse to membership categorisation devices (for example, that of father or mother, cf. the testimony of the father; cf. excerpt $n^{\circ} 9$ ) which render any intention which would be detrimental to himself incongruous. ${ }^{35}$ Conversely, any breach of this normal schema (for example, not informing the police of new information reported by the neighbours; cf. excerpt $n^{\circ}$ 9) must be redressed, this redress also being upheld by categorisation devices with which rights and duties are typically connected (for example, do not trust what is said by a small child; cf. excerpt $\mathrm{n}^{\circ} 9$ ).

The last category to be considered is that of the magistrate. By way of illustration, I shall return to the questions asked of the accused in a case of collective rape and the text of the inventory of the elements of proof, a document written by the substitute for the judges of the criminal court.

\section{4.}

\section{Minutes of the interrogation}

Taking advantage of the presence of the accused, we summoned prisoners who were outside the room in which the inquiry is conducted and asked them to respond to the accusations made against them, after having informed them that the public prosecutor had opened inquiry proceedings against them. They all accepted (having taken cognisance of the matter) and then we asked if they had a representative to appear with them for the inquiry proceedings. They

\footnotetext{
${ }^{34}$ Dulong, 1998, p. 42.
} 
responded in the negative. We had all the accused, except for the first one, leave the room. A young man in his thirties, approximately 1.70 metres and of average build and dark complexion, wearing a blue garment with checks at the bottom and a blue pullover, was examined. We questioned him as to details and he responded: (...)

Q: What are the details of what you admit? (...)

Q: Did you agree to take just any woman from the street? (...)

Q: What sexual acts did you commit with the victim (woman)? (...)

Q: Was the girl willingly in this situation? (...)

Q: Did the female victim go with you of her own will to the place where the female victim was assaulted? (...)

Q: You are accused of participating with others in abduction and rape by force. What do you have to say? (...)

Q: You are also accused of participating with others in the above-mentioned theft by force. What do you have to say?

Q: You are also accused of participating with others in abduction and illegal confinement. What do you have to say? (...)

Q: Do you have a past record? (...)

Q: Do you have anything else to say? (...)

End of the statement of the accused Anwar.

\section{Inventory of the elements of proof}

Miss (..), aged 17 years (..), testifies to the fact that she (...) was in the company of her fiancé $(\ldots)$ and that, while they were stopped in the car $(\ldots)$, the accused ... threatened them by exhibiting a knife (gazelle horn) and ordered her fiancé to get out of the car. (...) They forced them to get in the taxi driven by the fifth accused and they left for another place [where the first accused undertook to rape her] (...) when gunshots were heard. [They] hastened to get into the

\footnotetext{
${ }^{35}$ Watson, 1983.
} 
car ...), they then proceeded to an inhabited area and stopped in front of a building at the foot of which was a garage in which there was no car. The first accused got out and met the sixth accused, he then returned to the car and told the female victim to enter the garage. She obeyed the order while the sixth accused looked on. The first accused then took out a blanket and a cushion and put them in a room adjoining the garage into which the accused, with the exception of the sixth, entered. Each then removed his clothes and lied on her (...) But, she made every effort to resist them and was injured on her left hand as a result of her resistance. She added that the first accused, when he led her into the room adjoining the garage, took possession of two rings she was wearing.

$(\ldots)$

\section{Observations}

1. The first accused said (...) that he had agreed with the second, third, fourth and fifth accused to abduct just any woman whom they met and to rape her. (...) He admitted, in the minutes, at the renewal of his detention ... the same thing he had said in the minutes at his arrest.

2. The second accused said the same thing in the minutes at his arrest. (...) He admitted (...) that the first, third, fourth and fifth accused had stolen from the two victims by force, that he had stolen the watch of the male victim on the public thoroughfare by threatening to use the knife he carried and that he had kissed and seized the female victim.

3. The third accused admitted (...) the same thing (...) and he added that he had seized the female victim by force, had lain on her and had kissed her.

4. The fourth accused admitted the same thing as that stated by the first accused and he added that he had grasped the female victim, seized and kissed her; he also admitted (...) having participated in the rape of the female victim. (...)

5. The fifth accused admitted (...) the same thing (...) and he added that he had grasped the female victim, had seized and kissed her; he also admitted that he had agreed with the four first accused to abduct the female victim, to rape her and to steal what she possessed by force. 
6. The sixth accused admitted (...) that he knew that the female victim had been abducted and that he had received the two rings and gold chain in return for providing the place where the accused raped the female victim. (...)

Contrary to the victim, the accused or even the witnesses, the substitute for the public prosecutor - the figure of the magistrate in all our examples - saw no dilemma as regards morality, agency or credibility. In the accomplishment of his work, it is essential for him to produce an account fulfilling the formal conditions of the legal category (participation in the abduction and rape by force, theft by force, abduction and illegal confinement). He must construct legally relevant and definable facts (agreement of the accused = premeditation, nature of sexual acts $=$ rape, absence of willingness on the part of the victim $=$ force). In so doing, it is also indispensable for him to bring to light the individual (the terms "admit" and "commit", but also the observations formulated by each of the accused) and the intentional (the terms "agree", "admit", "know"). Moreover, because this takes place within the framework of his routine work which consists of daily repeated procedures within familiar precincts at a time in the legal process in which the professional participants are known as well as their different functions in a controlled sequence of the production of legality, the action of the substitute is above all extremely routinised. The document evidently reproduces a stereotyped formula composed of standardised questions which assumes, in its broad lines, the General Instructions Addressed to Public Prosecutors in Criminal Cases as established by a circular notice of the Public Prosecutor's office.

\section{Conclusions}

I have attempted, from a radically non-mentalistic perspective, to reintegrate the question of intention within a contextual framework. Phenomena such as motivation, purpose, intention, 
thought, affect, etc., can neither be reified nor disconnected from the fabric of action, interaction and context through which these phenomena are publicly manifested and hence become observable and relevant. ${ }^{36}$ Motives, purposes, reasons and intentions can, in effect, only be understood through systems of discursive exchange. In other words, the mental states and their imputation can only be understood in their linguistic publication. In this sense, we have developed a "praxiological understanding of the 'mental"."37

Although the examples given in this text are "small-scale objectives", it should nevertheless be noted, as underscored by Michael Moerman, that they are "sufficiently actual and unimputed to merit painstaking attention from students of the strategic use of speech and of the relations between intentions and actions". ${ }^{38}$ They make it possible to see, case by case, how these strategies are deployed and are adapted to greater ends.

To speak of intention in law assumes that it is understood in act and in context. In so doing, we have observed the action of three factors circumscribing this configuration: the interactional nature of the verbal act, the institutional context in which it is inscribed and the distribution of positions in this context. The intention, its content and the form which it takes upon which it has a bearing, vary from one individual to the next according to these factors. I have attempted to show that intention, in law, was not a transcendental property of volition, but a practical orientation. It is thus only in its punctual, contingent and local configurations within the constraining framework of its context at each different occasion that it can be analysed. The legal meaning of intention emerges not from pure legal logic, but from the legal environment and interactions. If the philosophy of law delineates, in the manner of Hart, the possible scenarios, on the other hand, it conceals the practical modes of the configuration. These are, however, precisely what constitute the subject of the sociology of legal action.

\footnotetext{
${ }^{36}$ Watson, 1998.

${ }^{37}$ Coulter, 1992.

${ }^{38}$ Moerman, 1987, p. 53.
} 


\begin{abstract}
Abbreviations
CEDEJ Centre d'Études et de Documentation Économique, Juridique et Sociale

CNRS Centre National de la Recherche Scientifique

EHESS Ecole des Hautes Etudes en Sciences Sociales

LGDJ ???
\end{abstract}

\title{
Bibliography
}

- Arnaud, A. J., "Liberté", in A. J. Arnaud et al., ed., Dictionnaire encyclopédique de théorie et de sociologie du droit, deuxième édition corrigée et augmentée, Paris, LGDJ, 1993, pp. 345-346

- Canto-Sperber, M., ed., Dictionnaire d'éthique et de philosophie morale, Paris, PUF, 1996.

- Coulter, J., "Cognition in an ethnomethodological mode", in G. Button, ed., Ethnomethodology and the Human Sciences, Cambridge, Cambridge University Press, 1992, pp. 176-195

- Drew, P., "Contested Evidence in Courtroom Cross-Examination: The Case of a Trial for Rape", in P. Drew and J. Heritage, ed., Talk at Work: Interaction in Institutional Settings, Cambridge, Cambridge University Press, 1992, pp. 470-520

- Drew, P. and Heritage J., ed., Talk at Work: Interaction in Institutional Settings, Cambridge, Cambridge University Press, 1992.

- Dulong, R., Le Témoin Oculaire. Les conditions sociales de l'attestation personnelle, Paris, Editions de l'Ecole des Hautes Etudes en Sciences Sociales, 1998.

- Dupret, B., "The Person in an Egyptian judicial Context: An Ethnomethodological Analysis of Courtroom Proceedings", International Journal for the Semiotics of Law, 16(1), 2003, pp. 32-57.

- Engel, L., "Vers une nouvelle approche de la responsabilité. Le droit français face à la dérive américaine", Esprit, June 1993, pp. 13-27.

- Garfinkel, H., Studies in Ethnomethodology, Cambridge, Polity Press, 1967.

- Hart, H. L .A. and T. Honoré, Causation in the Law, Oxford, Clarendon Press, second edition, 1985 (first printing, 1959).

- Hart, H. L. A., The Concept of Law, Oxford, Oxford University Press, 1961.

- Hart, H. L. A., Punishment and Responsibility: Essays in the Philosophy of Law, Oxford, Clarendon Press, 1968.

- Heritage, J., Garfinkel and Ethnomethodology, Cambridge (United Kingdom), Polity Press, 1984.

- Jackson, B. S., Law, Fact and Narrative Coherence, Liverpool, Deborah Charles Publications, 1988.

- Jackson, B. S., Making Sense in Law. Linguistic, Psychological and Semiotic Perspectives, Liverpool, Deborah Charles Publications, 1995.

- Komter, M., Dilemmas in the Courtroom. A Study of Trials of Violent Crime in the Netherlands, Mahwah (New Jersey), Lawrence Erlbaum Associates, 1998.

- Mauss, M., "Une catégorie de l'esprit humain: la notion de personne, celle de 'moi"", Sociologie et anthropologie, Paris, PUF (extract from Journal of the Royal Anthropological Institute, v. LXVIII, 1938), 1950, pp. 333-361

- Moerman, M., Talking Culture, Cambridge, Cambridge University Press, 1987. 
- Neuberg, M., "Responsabilité", in M. Canto-Sperber, ed., Dictionnaire d'éthique et de philosophie morale, Paris, PUF, 1996, pp. 1306-1312.

- Ricœur, P., Le Juste, Paris, Esprit, 1995.

- Sacks, H., "Notes on Police Assessment of Moral Character", in D. Sudnow, ed., Studies in Social Interaction, New York, The Free Press, 1972, pp. 280-293

- Schutz, A., Collected Papers 1. The Problem of Social Reality, Dordrecht/Boston/London, Kluwer Academic Publishers, 1990 (first printing, 1962).

- Stockinger, P., "Autonomie", in A. J. Arnaud et al., ed., ., Dictionnaire encyclopédique de théorie et de sociologie du droit, deuxième édition corrigée et augmentée, Paris, LGDJ, 1993, pp. 47-49

- Watson, R., "The Presentation of Victim and Motive in Discourse: The Case of Police Interrogations and Interviews, Victimology: An International Journal 8/1-2, 1983, pp. 31-52

- Watson, R., "Catégories, séquentialité et ordre social. Un nouveau regard sur l'oeuvre de Sacks", in B. Fradin, L. Quéré and J. Widmer (dir.), L'enquête sur les catégories, Paris, Ed. de l'EHESS, 1994, pp. 151-184

- Watson, R., "Ethnomethodology, Consciousness and Self”, Journal of Consciousness Studies, 5/2, 1998, pp. 202-223.

- Wittgenstein, Ludwig, Philosophische Untersuchungen (Krit. Ausg. Hrsg. von B. McGuinness und J. Schulte), Francfort, Suhrkamp, 1989. 